\title{
Front Matter: Volume 10191
}

, "Front Matter: Volume 10191," Proc. SPIE 10191, Laser Radar Technology and Applications XXII, 1019101 (14 June 2017); doi: 10.1117/12.2281307

SPIE. Event: SPIE Defense + Security, 2017, Anaheim, CA, United States 


\title{
PROCEEDINGS OF SPIE
}

\section{Laser Radar Technology and Applications XXII}

\author{
Monte D. Turner \\ Gary W. Kamerman \\ Editors
}

11-12 April 2017

Anaheim, California, United States

Sponsored and Published by

SPIE 
The papers in this volume were part of the technical conference cited on the cover and title page. Papers were selected and subject to review by the editors and conference program committee. Some conference presentations may not be available for publication. Additional papers and presentation recordings may be available online in the SPIE Digital Library at SPIEDigitalLibrary.org.

The papers reflect the work and thoughts of the authors and are published herein as submitted. The publisher is not responsible for the validity of the information or for any outcomes resulting from reliance thereon.

Please use the following format to cite material from these proceedings:

Author(s), "Title of Paper," in Laser Radar Technology and Applications XXII, edited by Monte D. Turner, Gary W. Kamerman, Proceedings of SPIE Vol. 10191 (SPIE, Bellingham, WA, 2017) Seven-digit Article CID Number.

ISSN: 0277-786X

ISSN: 1996-756X (electronic)

ISBN: 9781510608832

ISBN: 9781510608849 (electronic)

Published by

SPIE

P.O. Box 10, Bellingham, Washington 98227-0010 USA

Telephone +1 3606763290 (Pacific Time) · Fax +1 3606471445

SPIE.org

Copyright (c) 2017, Society of Photo-Optical Instrumentation Engineers.

Copying of material in this book for internal or personal use, or for the internal or personal use of specific clients, beyond the fair use provisions granted by the U.S. Copyright Law is authorized by SPIE subject to payment of copying fees. The Transactional Reporting Service base fee for this volume is $\$ 18.00$ per article (or portion thereof), which should be paid directly to the Copyright Clearance Center (CCC), 222 Rosewood Drive, Danvers, MA 01923. Payment may also be made electronically through CCC Online at copyright.com. Other copying for republication, resale, advertising or promotion, or any form of systematic or multiple reproduction of any material in this book is prohibited except with permission in writing from the publisher. The CCC fee code is 0277-786X/17/\$18.00.

Printed in the United States of America.

Publication of record for individual papers is online in the SPIE Digital Library.

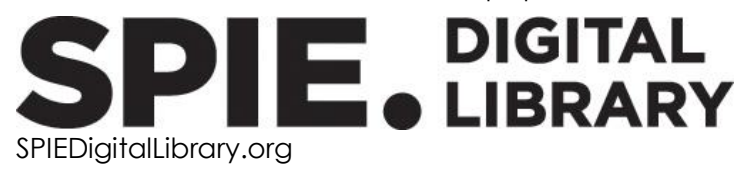

Paper Numbering: Proceedings of SPIE follow an e-First publication model. A unique citation identifier (CID) number is assigned to each article at the time of publication. Utilization of CIDs allows articles to be fully citable as soon as they are published online, and connects the same identifier to all online and print versions of the publication. SPIE uses a seven-digit CID article numbering system structured as follows:

- The first five digits correspond to the SPIE volume number.

- The last two digits indicate publication order within the volume using a Base 36 numbering system employing both numerals and letters. These two-number sets start with 00, 01, 02, 03, 04, 05, 06, 07, 08, 09, OA, OB ... OZ, followed by 10-1Z, 20-2Z, etc. The CID Number appears on each page of the manuscript. 


\title{
Contents
}

\author{
$\checkmark$ Authors \\ vii Conference Committee
}

\section{SESSION 1 SYSTEMS AND APPLICATIONS I}

1019102 Demonstration of coherent Doppler lidar for navigation in GPS-denied environments [10191-2]

1019103 Transient light imaging laser radar with advanced sensing capabilities: reconstruction of arbitrary light in flight path and sensing around a corner [10191-3]

1019104 Methane measurements from space: technical challenges and solutions [10191-4]

\section{SESSION 2 SYSTEMS AND APPLICATIONS II}

1019105 Improved TDEM formation using fused lidar/digital imagery from a low-cost small UAV [10191-6]

1019106 Doppler lidar power, aperture diameter, and FFT size trade-off study [10191-7]

1019107 Design of a cost-effective laser spot tracker [10191-8]

\section{SESSION 3 SYSTEMS AND APPLICATIONS III}

1019109 2D and 3D flash laser imaging for long-range surveillance in maritime border security: detection and identification for counter UAS applications [10191-10]

10191 OC Bathymetric depth sounder with novel echo signal analysis based on exponential decomposition [10191-13]

\section{SESSION 4 SIGNATURES AND PHENOMENOLOGY}

10191 OD Measuring laser reflection cross-sections of small unmanned aerial vehicles for laser detection, ranging and tracking [10191-14]

10191 OE Signatures of dynamical processes in Raman lidar profiles of the atmosphere [10191-15]

10191 OF Classification and identification of small objects in complex urban-forested lidar data using machine learning [10191-17]

$101910 G$ Signature stability in laser Doppler vibrometry [10191-18] 
10191 ol Visualization and analysis of lidar waveform data [10191-25]

10191 0J Spectral LiDAR analysis for terrain classification [10191-26]

\section{SESSION 5 DEVICES AND COMPONENTS}

10191 OK An auto-locked diode laser system for precision metrology [10191-19]

10191 OL A multi-wavelength IR laser for space applications [10191-20]

10191 ON Closed-loop control of gimbal-less MEMS mirrors for increased bandwidth in LiDAR applications [10191-22] 


\section{Authors}

Numbers in the index correspond to the last two digits of the seven-digit citation identifier (CID) article numbering system used in Proceedings of SPIE. The first five digits reflect the volume number. Base 36 numbering is employed for the last two digits and indicates the order of articles within the volume. Numbers start with 00, 01, 02, 03, 04, 05, 06, 07, 08, 09, OA, OB...0Z, followed by 10-1Z, 20-2Z, etc.

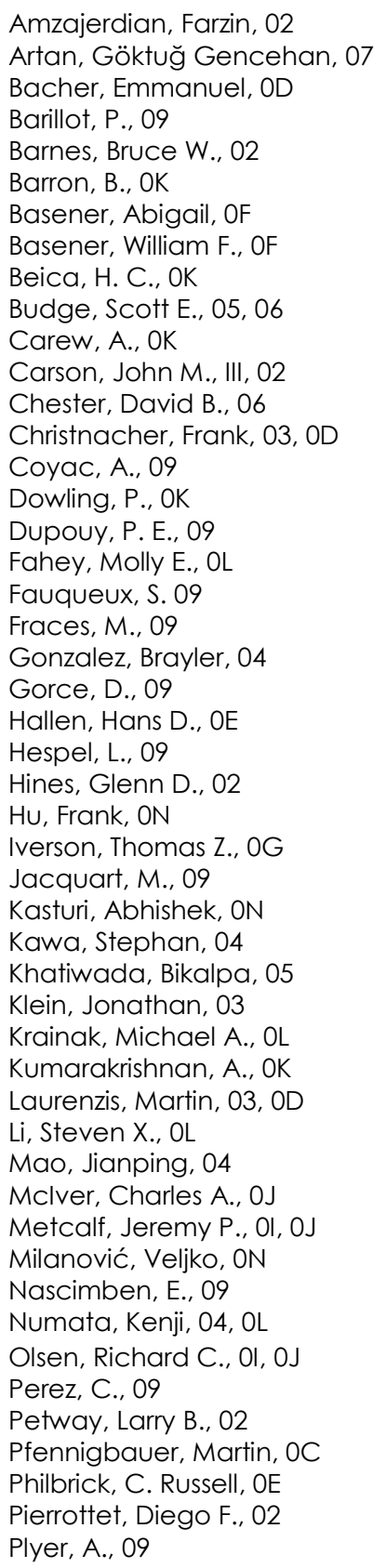

Pouliot, A., OK

Riris, Haris, 04

Riviere, N., 09

Rodriguez, Michael, 04

Sari, Hüseyin, 07

Schwarz, Roland, OC

Sun, Xiaoli, OL

Tauvy, M., 09

Ullich, Andreas, $0 \mathrm{C}$

Velayguet, J. P., 09

Vin, I., 09

Vorozcovs, A., OK

Watson, Edward A., OG

Wu, Stewart, 04

Yang, James, ON

YU, Anthony W., OL 
Proc. of SPIE Vol. 10191 1019101-6

Downloaded From: https://www.spiedigitallibrary.org/conference-proceedings-of-spie on 26 Apr 2023 Terms of Use: https://www.spiedigitallibrary.org/terms-of-use 


\section{Conference Committee}

Symposium Chair

Donald A. Reago Jr., U.S. Army Night Vision \& Electronic Sensors

Directorate (United States)

Symposium Co-chair

Arthur A. Morrish, Raytheon Space and Airborne Systems

(United States)

Conference Chairs

Monte D. Turner, Air Force Research Laboratory (United States)

Gary W. Kamerman, FastMetrix, Inc. (United States)

Conference Program Committee

Philip Gatt, Lockheed Martin Coherent Technologies (United States)

Dominique Hamoir, ONERA (France)

Richard M. Heinrichs, MIT Lincoln Laboratories (United States)

Thomas J. Karr, Defense Advanced Research Projects Agency (United States)

Lori A. Magruder, Applied Research Laboratories, The University of Texas at Austin (United States)

Vasyl Molebny, National Taras Shevchenko University of Kyiv (Ukraine)

C. Russell Philbrick, North Carolina State University (United States)

Upendra N. Singh, NASA Langley Research Center (United States)

Ove Steinvall, FOI-Swedish Defence Research Agency (Sweden)

Grady H. Tuell, 3D Ideas, LLC (United States)

Douglas G. Youmans, Parsons Corporation (United States)

Session Chairs

1 Systems and Applications I

Gary W. Kamerman, FastMetrix, Inc. (United States)

2 Systems and Applications II

Monte D. Turner, Air Force Research Laboratory (United States)

3 Systems and Applications III

C. Russell Philbrick, North Carolina State University (United States) 
4 Signatures and Phenomenology

Douglas G. Youmans, Parsons Corporation (United States)

5 Devices and Components

Monte D. Turner, Air Force Research Laboratory (United States) 